\title{
The politics of thinking and the idea of the university as a heterotopia
}

\author{
Bregham Dalgliesh
}

\begin{abstract}
Drawing on struggles between academe as a place that historically harbours critique and new public management that fosters instrumental knowledge, I reimagine the university as a counter-space for thinking. Initially, I deploy the work of Scott Lash to show how informational capitalism suffocates critique. Notwithstanding, his solution of Informationskritik resigns itself to the monism of technoculture. I therefore turn to Jacques Derrida's idea of the university in relation to informationalisation. To ensure its autonomy, the university is supplementary to society, yet associated by its reflexivity that is on behalf of society. Finally, I invoke Michel Foucault's notion of heterotopia, which tracks the tendency of society to instil homotopic spaces of sameness. Such a blueprint of the university as a heterotopia acts as a barometer of the critical credentials of reason that is manifest in social practices. In parallel, it carries forward Derrida's idea for it and resuscitates a space for critical thinking.
\end{abstract}

Keywords: Foucault; heterotopia; critique; university; Derrida; informationalisation.

\section{The malaise between the university and society}

Historically, institutions of higher learning and the societies that beget them have coexisted. In ancient Egypt, epistemological endeavours served government administration, while from the Greek polis through to scholasticism ontological reflection informed social existence (Pedersen, 1997: ch. 1; Makdisi, 1989). More recently, in Prussia academic freedom was added to the university to construct the critical capacities of citizens (Hohendorf, 1993; Brubacher, 1977), while in America disciplinarity and professionalisation were incorporated to foster public service education (Post, 2009; Miyoshi, 2000). Lately, however, relations between the university and society reflect a 'malaise' (Hutnyk, 2021: 127). The culprit is less a time and place than a neoliberal reorganisation of institutions into "corporate menageries' (Hutnyk, 2021: 123). Riffing off this discourse, which ultimately seeks to 'inoculate capitalism against the threat of democracy' (Slobodian, 2018: 2), a populist New Public Management (NPM) ethos - do more with less - tolerates the survival of the idea of the university but stymies its realisation.

Survival is the operative word, too. In its relocation from the acropolis to the agora (Cowen, 2007: 96), a chasm emerges between the university's 'intellectual and moral achievements' (Rothblatt, 2013: 208). 
The authority of the former derives from the accomplishments of the positive sciences (whose quantifiable output valorises NPM methods), whereas the parsimony of moral attainments of the normative sciences (whose qualitative fruits undermine NPM techniques) engages them in a constant struggle for recognition. The disconnect generates a dilemma of how to combine advanced research and specialised teaching with a commitment to (democratic) 'personality formation' and the 'public university' (Wittrock, 2013: 215; Marginson, 2006: 47). Although such quandaries cut across all dimensions of society, I limit my remit to the organisational battle in the university between accessibility and excellence, where faculty concerned with a critical remit for knowledge are subject to managers focused on efficiency for competitive advantage (Calhoun, 2006: 9). In short, is it possible to reconcile the idea of the university as a community of scholars engaged in critical teaching and learning with neoliberal society saturated with NPM standards?

Despite the logic of NPM and contemporary technological culture, which together undermine the idea of the university as a place of critique, I claim we can salvage this ethos if we reimagine the university less as a place than a space with a 'capacity to develop unique forms of life' (Marginson, 2006: 44-45). To begin with, I substantiate the threat by detailing global informational capitalism and its NPM governance regime. In the second section I draw on Scott Lash, who takes up the NPM challenge in the philosophical register of a cult(ure) of information. He argues that what characterises our current infocomm society is the colonisation of the subject by the technoscientific environment and the usurpation of thinking by informational flows and incessant communication. Similarly, Jacques Derrida (1983: 14; 2002: 202) says the university's 'total subjection to the technologies of informatization' threatens the very existence of its guiding idea, which is the 'unlimited commitment to the truth.' I outline Derrida's analysis in the third section, where he offers an account of the university as the preeminent space of the prerogative of critique precisely because, like Angelus Silesius' rose, it can flourish there without a reason - Die Ros ist ohn warum - which makes the argument for the university as the home of reason both epistemological and ontological. ${ }^{1}$ Finally, in response to the conflation of places of reflection with techno-culture, I propose a reading of Michel Foucault's heterotopia as a conceptual infrastructure that can uphold the university as a space of thought and sustain Derrida's idea of it at the same time.

\section{Informational capitalism and NPM}

Information capitalism is a politically calculated rupture with industrial capitalism (Parayil, 2005: 1). Yet it is not coextensive with contemporary technological developments; rather it evolves with the 'capitalist mobilisation of society' itself (Robins and Webster, 1999: 4). Informationalisation is born of 
struggles over 'access to, and control over, information resources,' and derives from the domination inherent to capitalism (Robins and Webster, 1999: 91; Schiller, 2006: 173). Notwithstanding, there has been a 'protracted episode of accelerated information commodification' since the 1980s, with professional self-employed producers of information enclosed by corporations, transformed into wage labour and their product - information - traded as a commodity (Schiller, 2006: 36 and 8-11). Inherent to this 'new techno-economic system' of informational capitalism are techniques of planning and control, which are sustained by technologies of mobilisation and surveillance (Castells, 1996: 14; Robins and Webster, 1999: 8). Consequently, the 'new social morphology' of informational capitalism transforms 'experience, power, and culture' (Castells, 1996: 500).

A core technique in this endeavour is NPM. With a pedigree in market economics rather than democratic theory, NPM assumes the public and private sectors differ merely by degree and that the accounting methods of the latter bring efficiency gains to the former (Lapsley, 2009). In respect of higher education, NPM's reasoning is twofold: firstly, property rights suggest inefficiencies if ownership (by society of the knowledge it funds) is separated from control (by the academic of society's resources); secondly, principal-agent theory hypothesises the moral hazard of underperformance when the principal, viz., society (or its delegate, the state), cannot observe the agent's activity, which for our purposes is academic work (Schubert, 2009: 1226). As a remedy, NPM reduces the operative decision-making remit of the state and gives greater strategic autonomy to the university. In return, organisational hierarchy is strengthened as university managers increase their power over the academic (Schubert, 2009: 1225). As a theory of optimal functioning on behalf of public accountability (Stoker, 1998; den Heyer, 2011), NPM deploys carrot and stick techniques to foist a short-term, outcome-driven culture on universities that are long-run and process-oriented (Verbeeten and Speklé, 2015). Insofar as NPM managers know the price of everything and the value of nothing, conflict inevitably arises. Following Craig Calhoun (2006: 10), who reminds us of 'an obligation of critical theory to ask reflexively about ... the institutional organization of knowledge,' I examine it from a philosophical angle in respect of the very idea of the university itself.

In response to the NPM culture of 'entrepreneurial utilitarianism' (Neave, 2013) and the transition of the university from a 'cathedral of learning' to a 'cathedral of earning' (Engwall, 2008: 9), Robert Anderson (2009: 43-44) conceives three scenarios: continue busines as usual with periodic tweaks to assuage its critics; declare the university dead and accept the shackles of NPM; or recognise multiple modalities of the university. For the third option, we need to envisage the idea of the university less as an imperative than a set of permanent tensions to be negotiated (Anderson, 2009: 45). Yet what exactly is the intellectual threat of NPM that brings a symbolically violent politics to the university? 
If we trace the idea of the university from its inception through to the present, we confront a crisis of identity provoked by NPM's performative rationality that undermines the university's humanistic ethos. Let us defer to Derrida's (1983: 19-20) inaugural lecture at Cornell University in 1983, where he establishes the conceptual stakes of the institution:

[The university is] a sort of supplementary body that ... [society wants to] project outside itself and to keep jealousy to itself, to emancipate and to control. On this double basis, the university ... [is] supposed to represent society['s] ... views, conflicts, contradictions, its play and its differences.... But with the relative autonomy of a technical apparatus, ... the university has reflected society only in giving it a chance for reflection, that is also, for dissociation.

Derrida suggests the university is defined by its potential to overcome the 'systemic stupidity' of informationalisation (Featherstone, 2019). The challenge is to procure the university as a heterotopic space, especially if we adhere to the idea of it dissociated from society on behalf of a reflection upon it. In this respect, truth is the victim of the reign of information that blurs the 'metaphysical and the technical' (Derrida, 1983: 14). Fundamental research that is curiosity driven and has no immediate benefit is decommissioned in favour of instrumental knowledge with concrete applications. The former encapsulates the founding idea of the university and is menaced by NPM that engulfs it in much the same way that the lip of a peeling wave closes out the sanctity of the tube for the surfer. In McLuhanesque terms, the technological delivery of information does not merely inform through content, it (trans)forms thinking itself.

\section{Lash and techno-culture as the death knell of thinking}

It is this predicament that inspires Scott Lash's Critique of Information, where he advocates Informationskritik to immunise us from the 'liquidation of maturity through the systemic generalization of minority' (Stiegler, 2015: 3). Lash says it is the main threat of the info-comm society, which signifies that information is the principle of society, the key explanatory factor of its burgeoning new orders and the unifying principle of its disruptive processes. When this 'logic of information' becomes the leitmotiv of the economy, Lash (2002: 2-3) says the message becomes 'the paradigmatic medium of the information age' and takes the form of 'communication,' which is byte-like, compressed, ephemeral, instantaneous and, to boot, beyond any 'systemic conceptual framework.' To the extent information is the principle of society, communication its message and the capitalist market economy its engine, "sociality becomes displaced by a certain "informationality" (Lash, 2002: 75). As the cradle of a technological culture, the info-comm society transmogrifies power (as Castells argues above). Instead 
of its transmission via discursive knowledge, power is informational, or non-linear and discontinuous. It is proprietary, hence exclusionary, and constantly reconfiguring boundary objects (Lash, 2002: 177201). Because informational power dethrones critique, thinking becomes just another cultural artefact that is packaged as information. It hereby loses its licence to operate in a zone that is transcendental to the empirical. In Derrida's register, society reins in and reasserts control of the university through the conduit of information and the trojan horse of NPM.

What is the solution? Lash initially demarcates an epistemological attitude from that of an ontological ethos. The former turns on a subject that attributes logical meaning to things via the mirror of words, while in the mode of being of the latter meaning is grasped through phenomenological experience. Both presume an independent empirical world that can be thought from the outside: from the top-down, or transcendentally, by the representational subject, and from the bottom-up, or through a deep ontology, by the intentional subject. In contrast, Lash (2002: 17) argues for a radical monism of technology where meaning is neither epistemological nor ontological; it is empirical. As forms of life lift up and collide with informationalisation that come down into things, we experience a conflation of the subject with the object, ontology with epistemology, and discourse with the artefact (Lash, 2002: 215-216). We now make sense of our biological, cultural, social and ethical forms of life through operational technological systems, which makes us human-machine interfaces within a cybernetic self-regulating system.

Processes of mediated and contingent social existence - identity at a distance - come at a cost. Beingsin-the-world are all at sea as beings-in-the-globe, or a body without organs that is opened up, dispersed and externalised in info-comm flows. The cause is the radical tripartite impact of informationalisation on our forms of life (Lash, 2002: 15-16). Firstly, they are flattened, or the dualism between epistemology and ontology is conflated by information. Secondly, technological forms of life are non-linear. Meaning is parcelled up into units of information, with humans left to make sense of the chaos of high-speed, extended data that assails them and outpaces their capacity for reflection. Finally, because technological forms of life are disembedded, they produce a uniformity of meaning across space. These three tendencies mean beings-in-the-globe negotiate who they are in relation to spaces that are communicatively generic, albeit communally empty. Lash sounds the death knell of reflection due to the info-comm society that stunts reflexive self-formation. Knowing equates to doing and tallies with the flattening of the interiority of the subject, for whom making sense is 'account-giving, it is "glossing"... There is no time, no space for ... reflection[;] ... reflexivity becomes practice; it becomes communication' (Lash, 2002: 17-18). 
The question is what sort of critique is possible when theory itself is immanent to the info-comm order? For Lash, the creative alternative to the destruction of critique by informationalisation is media theory. It replaces critical theory that explains and social theory that interprets, as even texts and thought have become mediated, technological objects. There is no longer the reader who reflects, but the user who tweets streams of consciousness and ingests brute facts that are consummated in a Baudrillardian ecstasy of communication. If, by definition, theory requires a place for thought to ruminate, media theory may turn out to be a contradiction in terms, but it is 'our fate in the global information order' (Lash, 2002: 77). Yet how can media theory, which must resign itself to non-linear units of culture in the guise of communication that are high speed and transient, produce a critique of the order of which it is part indeed, can a critique of information 'come from inside the information itself' (Lash, 2002: vii)?

As stated earlier, Lash places his faith in Informationskritik. He argues that what links other modes of critique, from Adorno to Habermas and Foucault to Derrida, is a Heideggerian ontology that is divorced from practice. To be sure, these philosophers diverge in their interpretations of the world, but they all advocate a critique of the empirical from the standpoint of the transcendental. In his search for a mode of critique that is firmly rooted in technological forms of life, Lash (2002: 10) turns to Henri Lefebvre's metaphor of the spider that extends itself in space by spinning a web. Transposing this materialist metaphysics to the info-comm society, Lash posits we take on the characteristics of the spider to democratise it. Our own web would therefore constitute a space within the larger network (Lash, 2002: 116-124). To understand what mode of reflection is possible from our spatial web, Lash invokes Walter Benjamin's account of the storyteller. My web now takes on the form of a place in which I erect a ladder from the top down to connect with past experiences (Lash, 2002: 130-138). In contrast to Paul Klee's Angelus Novus that moves backwards into the future, the retrieval of memories by moving forwards into the past confronts the subject with their own mortality. Provoked by informational overloads of the network, the storyteller's memories of difference constitute the transcendental moment proper to reflection. They imply a politics of melancholy that is firmly anchored in the storyteller's traditions, without which we risk an 'politics of irresponsibility' (Lash, 2002: 140).

If the defining feature of the info-comm society is the subordination of information as discursive (social) knowledge to information as artefactual (cultural) communication, the effect is a 'dis-informed information society' that must defer to a media theory of the ephemerality of communication (Lash, 2002: 141-146). The appropriate attitude to adopt in this context is that of agonistic play with our technocultural existence through spinning webs of meaning (Lash, 2002: 157-164). As we saw earlier, sensemaking is no longer the prerogative of a subject that stands outside practice, but the activity of subjects that render meaning in their shared techno-culture. It is a mode of self-formation that is external, 
resolutely empirical and immanent, which is necessary given Lash's (2002: 76) argument that critique cannot operate outside the (info-comm) text.

\section{Derrida on reason and the time of the university}

Albeit perspicacious, Lash's take on the info-comm society is not without hiccups. Firstly, his perspective on the relationship between technics and ontology is ingenuous. Because he accepts the liberal point of departure of a pristine ontology that is free of technics, he cannot but conclude that subjectivity is suffocated by informational capitalism. ${ }^{2}$ Yet Bernard Stiegler (1998) comprehensively scuppers the view of beings-in-the-world (or, in Lash's version, beings-in-the-globe), who exist outside technics. Without any essence, we are beings-in-default, which makes us dependent on technics and all the better for it once we sober up to the fact. Secondly, Lash's claim that critical thought from Kant and Hegel to Derrida and Foucault depends on a transcendental realm that stands outside the empirical is moot. The écart is really a heuristic device. It is better to see the view from nowhere as no more than an aspiration for critique, if not thinking, tout court. Even though the body always has the last laugh, reason's desire to be autonomous in its practice - and the constant thwarting of it by the empirical - is not a cue to abandon critique in favour of a media theory of the technical, but an injunction to historically ground it (Dalgliesh, 2017: 219-227). Although Lash correctly interprets the threat to critique of the info-comm society and its colonisation of spaces of reflection, his fetishisation of the gap means he can only envisage a media theory at the other extreme of technically saturated social space. And, as he himself says, in such a location Informationskritik may well be a contradiction in terms.

As beings-in-default, the predicament of techno-culture is therefore nothing new. Rather, the present variant of the info-comm society is simply the terminus of a historical process that shatters the frontiers - or perhaps illusion - between embodied autonomy and technics. Notwithstanding, Lash's concern about the challenge to the idea of the university by informationalisation remains. How we confront it depends on reconfiguring the university's spatio-temporal architecture. In the next section, we consider the heterotopia as a means to sustain the idea of the university. The immediate aim here is to investigate whether the idea itself is still viable.

In his meditations on the purpose of the university in our techno-cultural times, Derrida (1983) claims that what distinguishes the rational animal from other species is our involuntary curiosity to know. We continuously amass percepts through the impulsion of visual perception. Our subjection to seeing in turn prompts a craving to cogitate the images we accumulate. Yet, if seeing drives the desire to know, how 
do we go the extra mile and learn something? Derrida says hearing is the key sense that enables us to acquire the skills necessary for the mind to transform its images into concepts. Seeing and hearing allow us to observe and listen, which are the cornerstones of knowing and learning. In other words, the ocularauditory dyad grounds the university's purpose as an interactional place of research and teaching, respectively. We hereby return to the initial question of the university's raison d'être. If humans cannot help but know and yearn to learn, the language in which they undertake them is reason. Likewise, the place that manufactures and dispenses reason is the university, which complements our very being that apprehends the world through the gifts of sound and vision.

The form of reason Derrida has in mind is that of non-contradiction and truth. It is not within our scope to unpack the latter, suffice to say it is a problematisaton of truth in relation to its genealogy, context of production and ethical imperatives (Derrida, 2002: 202-203). For example, the reign of reason is complicated by the need of global 'techno-economic networks' to always commodify research that is the product of poesis (Derrida, 1983: 11). It is aggravated by the fact that the idea of the university as an autonomous place that produces knowledge is flooded by information and subject to the diktats of NPM (Trifonas, 2000: 126-127). In response to 'the call of the principle of reason' within the info-comm society, it is the university that takes on the burden of responsibility (Derrida, 1983: 8). Yet what is the reason for the principle of reason itself? In fact, Derrida argues, none can be provided. However, this is not a cue for society to assert control over the university. Instead, it is better to acknowledge the abyss beneath the groundless ground - 'the "without-reason" of the world' (Nancy, 2007: 47) - than gloss over its absence and invite the usurpation of the idea of the university by entrepreneurial utilitarians. ${ }^{3}$ Based on an unconditional right to be the 'ultimate space of critical resistance,' the university is duty bound to 'reflect upon, invent and set down' the reasons for such a privilege (Derrida, 2001: 14-15). In assuming responsibility for its unconditional right to reason, the university must constitute a community and engender an institution, albeit quite different from what we usually understand by these terms.

As a community of thought, the perpetual task of the university is to unmask the ruses of reason by excavating its conditions of possibility, especially at the limits of the authority of reason where the logic of praxis and the conventions of NPM blur the line between fundamental and instrumental knowledge. Further, the 'community of questioning' (Trifonas, 2000: 128) teaches students how to counter-evaluate technically oriented ends, surveys the virtues of the principle of reason itself and highlights the aporia upon which it is grounded (Derrida, 1983: 14). From an institutional perspective, the university is a space in which the value and meaning of truth are articulated, or everything within the remit of the language of reason, which may simply demand an analysis of its extra-institutional manifestations that do not conform to the principle of it (Derrida, 1983: 16). In this way the university provides society with 
a mirror of itself in virtue of its obligation to produce knowledge and foster thinking from within an autonomous, communal place of thought that has taken on board the reality check of the imbroglio of information and knowledge. ${ }^{4}$ Lastly, Derrida (1983: 19-20) says the time of this reflection has a threefold character: its own internal rhythm, because the university is relatively independent of social time; a genealogical time that enables a turning back to analyse how we have got where we are; and, thirdly, an unconstrained time, which fosters heterogeneous thought to revitalise the social body.

\section{Foucault and the university as a heterotopia}

Based on Derrida's vision of how the idea of the university can prosper, I turn to examine the institution itself. Is it sufficient to simply embed reason - albeit purged of any pretention to have a reason other than itself - inside a campus enclosed by walls, gates and guards when the info-comm techno-culture that undermines it travels through cables, antennae and waves? Rather than think the university as a place, we might conceive it as a space that nurtures the three moments of time above and safeguards Derrida's idea from the Chokerlebnis of information that Lash reveals.

Motivated by his experience as an outsider in Tunis in 1966 (Faubion, 2008: 31), Foucault's conception of space as an unfamiliar yet affective place, with its own rites and adherents, offers a solution. He calls it a heterotopia, or a different [heteros] place [topos], which begs the question, different how? Firstly, it is an actual space and should not be confused with its sibling, utopia, which is a place that is nowhere [outopia] and, perhaps because of its mythical status, a good place [eutopia]. Yet they form a continuum - or perhaps one is the theory of a place and the other the practice as a space - since a heterotopia is an 'effectively enacted utopia' (Foucault, 1984: 24; Bradley, 2019). Secondly, even though it is a product of its environment, a heterotopia is an idea about the pragmatics of space (Genocchio, 1995: 43). After the original medical term, a heterotopia is dislocated, non-pathological tissue. It is an apparition that is out of place [ektopia] - both a 'spatial and morphological anomaly' (Sohn, 2008: 43) - yet it is connected to healthy tissue. Similarly, Foucault's heterotopia occupies a space in the social order (for example, the tourist resort or cram school), which is at an imaginary remove from society rather than physically separated from it (Gosling, 2014: 44). And, thirdly, because a heterotopia compensates for the shortcomings and overflows of social space proper, it has critical credentials. Somewhat like an apparatus of capture, a heterotopia gathers up the lacunae and paradoxes of social life. Via its 'demonising imagination,' which is constituted by and constitutive of 'quotidian' society, a heterotopia contests the social ordering of space (Faubion, 2008: 39). 
A year later Foucault lectured to an audience of architects in Paris, which was published as "Des espaces autres" in the year he died, 1984. The English version first appeared in 1986 under the title, "Of other spaces" (translated by Jay Miskowiec), a second version, "Different Spaces" (translated by Robert Hurley), emerged in 1998 and a third, which kept Miskowiec's title (translated by Lieven De Cauter and Michiel Dehaene), was published in 2008. The first problem concerns the concept of espace itself. Although typically translated as space, Foucault has more in mind and uses the word emplacement. It captures both the imaginary sense of space [espace], which is an abstract idea that might describe an area or a distance, and a place [lieu] that is more concrete and related to an event. An emplacement both demarcates (a space) and designates (a place). ${ }^{5}$ It differs from organisational container spaces that are 'haunted by the ghosts of those whose exclusions we no longer witness' (Huffer et al., 2018: 77). ${ }^{6}$ Similarly, in contrast to medieval notions of hierarchical space, classic ideas of infinite space and the phenomenological sense of internal space, emplacement defines 'the [grid-like] relations of proximity between points' (Foucault, 1998: 176-177). As such, unpacking a heterotopia as a 'spatio-temporal unit' (Defert, 1997: 44) depends on an understanding of the society that conditions the possibilities of its relationships (Foucault's 1984: 23), which makes it less like an object of study and more akin to an archive that documents society's anomalies (Johnson 2013: 783 and 795).

A second difficulty concerns the translated titles, which imply Foucault's heterotopia can be interpreted either as a celebration of otherness (cf. Miskowiec; Hetherington, 1997), or as a harbour of difference (cf. Hurley; Soja, 1996). ${ }^{7}$ The first implies a radical space of alterity, a counter-power. As a site exogenous to the social, it is what Foucault digs for in his search for extra-European critical inspiration, or his archaeology of extra-discursive madness (Dalgliesh, 2017: 134). The second, which is the view I adhere to, suggests heterotopia is derivative of social space with the potential to affect it. In this sense, a heterotopia is a counter-space that diverges from, yet is transformative of, everyday life. As a rhetorical machine (Faubion, 2008: 33), it falls outside the ordering of social space by reason; it is a 'slip in time' that collects those superfluous to such a logic (Redmond, 2015: 63). Following Robert Harvey (2017: 103), heterotopias are not only different spaces, but 'spaces otherwise:' des espaces autres are spaces apart that are 'elsewhere than where you or I live,' yet they are not severed from the social and remain 'uncannily and insistently here;' it makes them uninhabitable, 'different, apart from us,' yet our relation to them means heterotopias are 'inextricably, uncannily part of us: part of us is there. ${ }^{8}$

Foucault's gesture at the concept of heterotopia signals a switch in epoch from time to space (Huffer et al., 2018: 79). The world has become a mosaic of heterogeneous spaces that are a concurrent, contrasted and contiguous network of emplacements in which processes of becoming are mediated. Although Foucault never gets around to a full heterotopology, his tentative 'spatial analytics' (Boyer, 2008: 53) 
specifies heterotopias as those emplacements whose critical link to society neutralises, compensates and inverts its relations (Johnson, 2006: 84). They highlight the "friction between what is socially normative and what is peculiar to itself, between the day-to-day activities of a given society and how [heterotopias depart] ... from the rules and norms of this society' (Derek Hook quoted in Dixie and Sey, 2017: 96).

Hence, the critical import of heterotopias (Foucault, 2008: 18-22). Firstly, they are universal. Even if context determines their form, heterotopias cater for a crisis without a specific site (the honeymoon), or a deviation that tends to drop anchor in an institution (the old age home). Secondly, heterotopias mutate. They change function according to the norms of society, which means the same designated emplacement might shift location to a different site to realise a new purpose (the cemetery). Thirdly, heterotopias are polyvalent mirrors. Through compartmentalisation they juxtapose in a single emplacement the contradictions, paradoxes and tensions of multiple social spaces (the garden). Fourth, heterotopias are temporal sites of discontinuity or accumulation. They are heterochronic insofar as they cater for those people or artefacts that are out of sync with normal social time (the museum); alternatively, heterotopias are chronic and pander to an immediate need (the boutique hotel). Further, they are orifical. Heterotopias isolate and are penetrable. By setting conditions for entry and restricting access even where membership is granted, they uphold ambivalence in their interiors (the love hotel). Finally, heterotopias are multifunctional: they are spaces of illusion that clarify real spaces of everyday life by unmasking their contingent foundations (the brothel vis-à-vis marriage); and they are perfect spaces, which compensate for the disorder of social space and offer a respite of sorts (the gated community).

Does the idea of the university encapsulate a heterotopia that is universal, mutates, polyvalent, temporal, orifical and functional? Curiously enough, Foucault does not mention the university as an example of a heterotopia, and contemporary scholarship mostly follows suit. Apart from Paul Patton's (Huffer et al. 2018: 82-83) idea of the networking space of the academic conference, Belinda du Plooy's (2018) view of the university as a productive space for a new South African identity, Erik Blair's (2009) assessment of the impact upon research of the further education college space, or the critiques of David Gosling (2014) and Lesley Gourlay (2015) that expose the neo-liberal pedagogical and ontological utopia lurking within the NPM discourse of excellence and openness, respectively, there are few attempts to think the university's connection to society on the basis of a heterotopia. ${ }^{9}$ However, in the spirit of Thomas Müller's Raumdeuter - an interpreter of space (Wilson 2020) - I argue it personifies one.

Most modern societies have formal emplacements for seeing and hearing in a common language of understanding (viz., reason). One could also argue they are deviations, whether from modes of thinking 
that shape mainstream life, neoliberalism's imperative of choice or the leisure that consumerism encourages. The deviation is an escape, with residence in the heterotopia of the ivory tower tolerated before insertion into society, which is self-styled as the real topos. And, as we know, universities mutate in accordance with the needs of society. They have been affirmed in their autonomy, diversified into research and stretched to alleviate elitism, which has often involved a change in location from the centre of the city to the outskirts and, more recently, the extension across space of the branch campus. Thirdly, the university is polyvalent to the point of its own downfall. In the single emplacement of the campus, it reflects the diverse and often incompatible interests of social space. Disparate fields of knowledge are compartmentalised into disciplines, which mirror the logic of the market, engineering projects, policies of government, segments of culture, a nation's needs, life's dreams or bio-social wants.

Insofar as temporality is concerned, the university is both out of sync and over synced. Schematically, the interpretive bent of the normative sciences makes them heterochronic. They feed off an archived stock of accumulated wisdom, whether the musty place of the library or odourless space of the data base. For their part, the positive sciences are chronic in the orientation of their research by concrete problems. They are forward looking and defined by the distance they can establish from their historical origins and the immediacy of their impact. Fifth, the university is a classic orifical order. Entry is fiercely competitive at the formal level, and radically ambivalent at the informal level of teams of research, funding allocations, committee membership or teaching distributions. Ironically, in the space where what you know ought to count the most, the driver of networked social space of who you know has its place, too. Lastly, the function of the university fulfils the twin tasks of mirrored Lichtung and Ordnung. Indeed, along with Derrida we could argue the university is grounded in the fantasy of the existence of a reason for reason; at the same time, however, the university reflects back this abyss. It unmasks the contingency of social norms and hereby reveals the illusions put in place in social space by the artifice of reason, which of course are a necessary medicine against nihilism. Conversely, the tendency to gloss over the absence of a ground for reason gives the impression the university is a perfect space of Ordnung. And the campus as a smart, self-contained and walled place fuels the fantasy. Hence, one is lucky to work there outside the chaos of the hic et nunc, or the student is indulged the luxury of a hiatus in the university between school and the real - albeit disordered - topos.

\section{A space of reason as a bulwark against an informational homotopia}

According to Simon Marginson (2006: 47), reimagining the university must factor in all three of its component parts: its inner capacity for self-alteration; the institutional framework of higher education; 
and the wider context in which the university is located. The second and third factors share globalisation in common: the second is positive if we frame it as internationalisation with a social mission (Dalgliesh, 2021); and the third that we have addressed - informational capitalism - is negative when seen from the perspective of the self-referential 'bullshit discourse' of NPM, which uses surveillance techniques to control university faculty (Lorenz, 2012: 600-601).

With regard to self-alteration, the university as a heterotopia encapsulates it. In such a form, it is no longer a place but a fluid intellectual space that outwits the info-comm flows that thwart the university's founding idea. As a counter-space established by society, the critical mission of the university is to track how reason always falls short of its ambition to constitute universal practices (Veyne, 1993: 5), which is a fortuitous failure insofar as society would otherwise resemble a totalitarian homotopia. It is here that Foucault merges with Derrida, for whom the university is a 'supplementary body' that society wants to emancipate and control. Like a child, the university yearns for autonomy yet finds it cannot go it alone without parental approval and money. Moreover, the parental determination of the university's remit the surveillance of reason as it is manifest in social practices - gives the child carte blanche to expose society's shortcomings. In pursuit of its critical task to act as the barometer of the universal pretensions of reason, the university in the form of a heterotopia often comes across as insolent, which explains why the umbilical cord is never severed and the angry parent often tugs at it and occasionally threatens to pull the university back into the womb.

Such an iteration of the university is arguably a bulwark against the intellectual downsizing of NPM and the colonisation of its spaces of thought by informational capitalism. As the supplementary space in which the prerogative of reason is paramount, it is the mobile brain of society from which no practice is spared scrutiny. In this sense, reason is a virtual entity that flows via the conduit of the heterotopic space of the university, which is akin to a ship, or a 'piece of floating space, a placeless place, that lives by its own devices, that is self-enclosed and, at the same time, delivered over to the boundless expanse of the ocean [viz. society]' (Foucault, 1998: 185). It is a reactive emplacement that is a network of individuals neither defined nor constrained by organisational boundaries. Such a heterotopia is not outside society - as the enclosed place of the campus symbolises - but within it, from where the university harvests society's problems and ponders them in the light of reason. And it does so because its members are bound by vocation to the idea of the university, which might foster peaceful coexistence with society once again. Through cleaving at our way of 'being, thinking, and judging' in relation to the everyday spaces we inhabit, the university as a heterotopia cultivates a society whose members 'function everywhere otherwise ... [and] respect other manners of being' (Harvey, 2017: 102). 
One needs to be sober about the university: at worst, society might indulge it as a space of illusion that challenges the social simulation of order, only to disarm it when it shouts too loud by tagging it as a deviation from the status quo, even though it is sanctioned to play this renegade role in the first place (Huffer et al., 2018: 80); at a minimum, though, the university as a heterotopia is a space of ethical compensation that is seamless and meticulous in juxtaposition to the messiness of social space (Foucault, 1998: 184). As such, it is the purveyor of reason, nothing more and radically insufficient because it lacks a ground for it, but along with all other creative endeavours these heterotopias proffer intellectual spaces at a safe distance from informationalisation, which is vital because in civilisations 'without ships, dreams dry up, espionage takes the place of adventure, and the police that of the corsairs' (Foucault, 1998: 185). Our failure to take heed of these words and imagine the university as heterotopia runs the risk of the rose of reason ceasing to bloom simply because it can; clipped from its stem by NPM, reason would take root in a totalitarian homotopia of informational capitalism that would have space for neither illusion nor compensation. 


\section{References}

Anderson, R (2009) The idea of a university. In: K Withers (ed.), First class? Challenges and opportunities for the UK's university sector. London: Institute for Public Policy Research, 37-45.

Blair, Erik (2009) A further education college as a heterotopia. Research in Post-Compulsory Education 14 (1): 93-101.

Boyer, M Christine (2008) The many mirrors of Foucault and their architectural reflections. In: Michiel Dehaene and Lieven De Cauter (eds.), Heterotopia and the City: Public space in a postcivil society. London: Routledge, 53-73.

Bradley, Joff P N (2019) Exhausted philosophy and islands-to-come. Educational Philosophy and Theory 51 (3): 265-274.

Brookfield, K (2018) Studentified areas as contested heterotopias: Findings from Southampton. Area 51:350-359. https://doi.org/10.1111/area.12458

Brubacher, J S (1977) On the Philosophy of Higher Education. San Francisco: Jossey-Bass.

Calhoun, Craig (2006) The University and the Public Good. Thesis Eleven 84 (1): 7-43.

Castells, Manuel (1996) The Rise of the Network Society. The Information Age: Economy, Society and Culture. Vol. 1. Malden, MA: Blackwell.

Cowen, R (2007) Effectivity, performativity and competition: Forms of domination in comparative perspective. In: H-G Kotthoff and S Moutsios (eds.), Education policies in Europe: Economy, citizenship, diversity. Münster: Waxmann, 89-100.

Dalgliesh, Bregham (2014) The philosophy of the liberal subject of technology: Michel Puech's homo sapiens technologicus. Philosophy \& Technology 27 (4): 595-602.

Dalgliesh, Bregham (2017) Critique as Critical History. New York: Palgrave Macmillan.

Dalgliesh, Bregham (2021) Reimagining internationalisation: the ethics of the organisational renovation of the national university. Educational Philosophy and Theory (under review).

Defert, Daniel (1997) Foucault, space, and the architects. In: Jean François Chevrie (ed.), Politics/poetics: documenta X-the book. Ostfildern-Ruit, Germany: Cantz Verlag, 274-283.

den Heyer, G (2011) New public management: A strategy for democratic police reform in transitioning and developing countries. Policing: An International Journal 34 (3): 419-433.

Derrida, Jacques (1983) The Principle of Reason: The University in the Eyes of Its Pupils. Diacritics 13 (3): 2-20.

Derrida, Jacques (2001) L'Université sans condition. Paris: Editions Galilée.

Derrida, Jacques (2002) The university without condition. In: Peggy Kamuf (ed. and trans.), Without Alibi. Stanford: Stanford University Press, 202-237.

Dixie, Christine and James Sey (2017) Wrapping Johannesburg: A boxing story. Thesis Eleven 141 (1): 86-102.

Engwall, Lars (2008) The university: a multinational corporation? In: Lars Engwall and Denis Weaire (eds), The University in the Market. London: Portland Press, 9-21.

Faubion, James D (2008) Heterotopia: an ecology. In: Michiel Dehaene and Lieven De Cauter (eds.), Heterotopia and the City: Public space in a post-civil society. London: Routledge, 31-39.

Featherstone, Mark (2019) Against the humiliation of thought: The university as a space of dystopic destruction and utopian potential. Educational Philosophy and Theory 51 (3): 298-309. 
Foucault, Michel (1966a) Les Hétérotopies. Radio broadcast. France Culture, 7 December. https://www.youtube.com/watch?v=lxOruDUO4p8

Foucault, Michel (1966b) Les mots et les choses : une archéologie des sciences humaines. Paris: Gallimard.

Foucault, Michel (1984) [1967] Of other spaces. Jay Miskowiec (trans.). Diacritics, 16: 22-27.

Foucault, Michel (1998) [1967] Different Spaces. Robert Hurley (trans.). In: J. D. Faubion (ed.), Aesthetics, Method, and Epistemology: Essential Works of Foucault Volume 2. London: Penguin, 175-185.

Foucault, Michel (2008) Of other spaces. Michiel Dehaene and Lieven De Cauter (trans.). In: Michiel Dehaene and Lieven De Cauter (eds.), Heterotopia and the City: Public space in a post-civil society. London: Routledge, 41-50.

Genocchio, B (1995) Discourse, discontinuity, difference: the question of other spaces. In: S Watson and K Gibson (eds.), Postmodern cities and spaces. Oxford: Blackwell, 35-46.

Gosling, D (2014) Teaching and learning projects as "Heterotopias." Critical Studies in Teaching and Learning 2 (1): 25-48.

Gourlay, L (2015) Open education as a "heterotopia of desire." Learning, Media and Technology 40 (3): 310-327.

Guan, Shanshan and Erik Blair (2021) Chinese adult higher education as a heterotopia. Higher Education 81: 471-489.

Harvey, Robert (2017) Sharing Common Ground: A Space for Ethics. London and New York: Bloomsbury.

Hetherington, K (1997) The badlands of modernity: heterotopia and social ordering. London: Routledge.

Hohendorf, Gerd (1993) Wilhelm von Humboldt. Prospects: the quarterly review of comparative education XXIII (3-4): 613-623. http://www.ibe.unesco.org/sites/default/files/humbolde.PDF

Huffer, Lynne, Steven Ogden, Paul Patton and Jana Sawicki (2018) Foucauldian Spaces: Round Table Discussion with Lynne Huffer, Steven Ogden, Paul Patton, and Jana Sawicki. Foucault Studies 24: 77-101.

Hutnyk, John (2020) The corporate menagerie. Thesis Eleven 160 (1): 121-128.

Johnson, Peter (2006) Unravelling Foucault's "different spaces." History of the Human Sciences 19 (4): 75-90.

Johnson, Peter (2013) The Geography of Heterotopia. Geography Compass 7 (11): 790-803.

Lapsley, I (2009) New Public Management: The Cruellest Invention of the Human Spirit? Abacus: Accounting, Finance and Business Studies 45 (1): 1-21.

Lash, Scott (2002) Critique of Information. London: Sage.

Lorenz, Chris (2012) If You're So Smart, Why Are You under Surveillance? Universities, Neoliberalism, and New Public Management. Critical Inquiry, 38 (3): 599-629.

Makdisi, George (1989) Scholasticism and Humanism in Classical Islam and the Christian West. Journal of the American Oriental Society 109 (2): 175-182.

Marginson, Simon (2006) Putting "Public" Back into the Public University. Thesis Eleven 84 (1): 4459.

Miyoshi, Masao (2000) Ivory Tower in Escrow. boundary 2 (27): 7-50. 
Moutsios, Stavros (2013) The de-Europeanization of the university under the Bologna Process. Thesis Eleven 119 (1): 22-46.

Nancy, Jean-Luc (2007) The Creation of the World, or Globalization. F. Raffoul and D. Pettigrew (trans. and introd.). Albany, New York: State University of New York Press.

Neave, Guy (2013) On Meeting the Mass in Higher Education. In: Mordechai Feingold (ed.), History of Universities, Vol. XXVII/I. Special Issue: The Modern University: Past, Present and Prospects: Essays in Honour of Sheldon Rothblatt. Oxford: Oxford University Press, 170-198.

Parayil, G (2005) Introduction: Information Capitalism. In: G. Parayil (ed.), Political Economy and Information Capitalism in India. London: Palgrave Macmillan, 1-10.

Pedersen, Olaf (1997) The First Universities: Studium generale and the origins of university education in Europe. Richard North (trans.). Cambridge: Cambridge University Press.

Plooy, B (2018) The strategic performance of heterotopic experiences in higher education: imagining spaces of potentiality for new South African identities. South African Journal of Philosophy 37 (4): 393-409.

Post, Robert (2009) Debating Disciplinarity. Critical Inquiry 35 (4): 749-770.

Redmond, Sean (2015) Extraordinary television time travel and the wonderful end to the working day. Thesis Eleven 131 (1): 54-64.

Robins, Kevin and Webster, Frank Webster (1999) Times of the Technoculture: From the Information Society to the Virtual Life. London: Routledge.

Rothblatt, Sheldon (2013) Review Essay: The Origins of Moral Ambiguity in the Academy. In: Mordechai Feingold (ed.), History of Universities, Vol. XXVII/I. Special Issue: The Modern University: Past, Present and Prospects: Essays in Honour of Sheldon Rothblatt, Oxford: Oxford University Press, 227-257.

Schiller, Dan (2006) How to Think about Information. Chicago: University of Illinois Press.

Schubert, Torben (2009) Empirical observations on New Public Management to increase efficiency in public research: boon or bane? Research Policy 38 (8): 1225-1234.

Slobodian, Quinn (2018) Globalists: The End of Empire and the Birth of Neoliberalism. Harvard: Harvard University Press.

Sohn, Heidi (2008) Heterotopia: anamnesis of a medical term. In: Michiel Dehaene and Lieven De Cauter (eds.), Heterotopia and the City: Public space in a post-civil society. London: Routledge, 41-50.

Soja, E (1996) Thirdspace. Oxford: Blackwell.

Stiegler, Bernard (1998) Technics and Time, 1: The Fault of Epimetheus. Richard Beardsworth and George Collins (trans.). Stanford: Stanford University Press.

Stiegler, Bernard (2015) States of Shock: Stupidity and Knowledge in the Twenty-First Century. Daniel Ross (trans.). Cambridge: Polity Press.

Stoker, G (1998) Governance as Theory: Five Propositions. International Social Science Journal 50 (1): 17-28.

Trifonas, Peter Pericles (2000) Technologies of Reason: Toward a Regrounding of Academic Responsibility. In: Peter Pericles Trifonas (ed.) Revolutionary pedagogies: cultural politics, instituting education, and the discourse of theory. London and New York: Routledge, 113-139.

Verbeeten, F and R Speklé (2015) Management Control, Results-Oriented Culture and Public Sector Performance: Empirical Evidence on New Public Management. Organization Studies 36 (7): 953978. 
Veyne, Paul (1993) The Final Foucault and His Ethics. Critical Inquiry 20 (Autumn): 1-9.

Wilson, Jonathan (2020) Bayern Munich's Thomas Müller the spaceman from a different galaxy. The Guardian, 19 August.

Wittrock, Björn (2013) The Modern University in Its Historical Contexts: Rethinking Three Transformations. In: Mordechai Feingold (ed.), History of Universities, Vol. XXVII/I. Special Issue: The Modern University: Past, Present and Prospects: Essays in Honour of Sheldon Rothblatt. Oxford: Oxford University Press, 199-226. 


\section{Notes}

${ }^{1}$ The university's 'reason for being has always been reason itself, and some essential connection of reason to being' (Derrida, 1983: 7).

${ }^{2}$ For the conceptual problems of the liberal view of the subject in relation to technology, see Dalgliesh (2014).

${ }^{3}$ Derrida (1983: 10) writes: 'The principle of reason installs its empire only to the extent that the abyssal question of the being that is hiding within it remains hidden, and with it the question of the grounding of the ground itself, of grounding as grunden (to ground, to give or take ground: Boden-nehmen), as begrunden (to motivate, justify, authorize) or especially as stiften (to erect or institute...).'

${ }^{4}$ An example of the university as a revitalised institution is the Collège Internationale de Philosophie established in 1984 with Derrida as its first director. The Collège dispels with the idea of the enclosed universitas; instead, it is institutionally designed around borderless knowledge and a transnational community of scholars (Trifonas, 2000: 129-133).

${ }^{5}$ For instance, I might demarcate my (picnic) space during a Spring Hanami (花見) party by laying down my ground sheet under the cherry tree, which I can only stake out in the designated place of a park.

${ }^{6}$ Cases in point are the 'fleetingly realised' (Johnson, 2013: 799) utopias (middle-class) children invent at the bottom of the garden (Foucault, 1966a). Language occupies different spaces, too, and Foucault (1966b: 3-10) cites Jorge Luis Borges' discovery of a Chinese encyclopaedia's classification of animals as an example.

7 De Cauter and Dehaene (2008: 22-23) navigate a middle path and claim Foucault is interested in a reflection on both alterity and difference, yet Robert Harvey's (2017) reading that I deploy below arguably refutes this.

${ }^{8}$ Spaces otherwise therefore divide and share (Harvey, 2017: 195-200). Like a Kloppian Gegenpressing strategy, they distribute each player into a given role but implicate them in a larger whole in terms of the spoils to be had from working the same space together. They invoke an experience of what Harvey (2017: 54) calls a 'cleft' (partager, which is both to set apart and share), or a sense of something that 'both cleaves [at our vey being] and enables cleaving to.'

${ }^{9}$ Related endeavours include reading student housing as a heterotopia of studentification within residential areas (Brookfield, 2018), or interpreting adult education as a holding space for the socio-political problem that arise during state reforms in China (Guan and Blair, 2021). 